\title{
Public Support of Solar Electricity and its Impact on Households - Prosumers
}

\author{
Jarmila ZIMMERMANNOVÁ, Adam PAWLICZEK, Petr ČERMÁK
}

\author{
Moravian University College Olomouc, tr. Kosmonautu 1288/1, 77900 Olomouc, Czech Republic \\ jarmila.zimmermannova@mvso.cz, adam.pawliczek@mvso.cz,petr.cermak@mvso.cz
}

\begin{abstract}
Background and Purpose: Currently, the idea of households - prosumers is broadly discussed in public governments, mainly in connection with both the energy security issues and the environmental issues. Therefore, the main goal of this paper is to present new agent model of household - prosumer and to compare two scenarios - "off grid household" and "on grid household". The additional goal is to evaluate the impact of public support of solar electricity on the economic efficiency of household - prosumer projects (systems).

Design/Methodology/Approach: The model is structured as a micro-level agent model, representing one household - prosumer. The model has the following general characteristics: one household with own electricity generation (photovoltaic panels), battery and in case of "on grid household" also connection to the grid. The main goal of the agent is to cover electricity consumption in household with minimal costs. The agent model of prosumer is tested and validated, using the empirical data.

Results: The highest level of subsidy has significant impact on the economic indicators of selected scenarios. It causes lower investment costs at the beginning of the project and consequently shorter payback period (3-4 years earlier), positive cumulative cash flow, net present value and IRR in earlier period (approximately 5-10 years earlier, depending on the scenario).

Conclusion: We can recommend to the government to continue with current system of subsidies, since it contributes to better economic indicators of particular solar electricity projects. On the other hand, the level of subsidy should be at least the same as in current year 2017, for the purposes of representing the significant part of the investment costs. Low level of subsidy has negligible impact on the economic indicators of households - prosumers projects. The developed agent model is suitable for the evaluation of economic impact of public support on households - prosumers.
\end{abstract}

Keywords: renewable electricity; photovoltaics; prosumers; households; public support; agent model; energy model

\section{Introduction}

\subsection{Policy introduction}

Energy efficiency and renewable energies have a great potential for economic development in Europe's regions by boosting energy security, creating jobs and increasing regional autonomy, as well as helping to fight climate change (Hunkin et al., 2014). The European Union has contributed greatly to the growth of these sectors in Europe, with the
Europe 20/20/20 targets setting the mid-term policy framework, and a variety of programmes and tools providing finance and support for regional development.

Based on Directive 2009/28/EC of the European Parliament and of the Council of 23 April $2009^{1}$ on the promotion of the use of energy from renewable sources and amending and subsequently repealing Directives 2001/77/ $\mathrm{EC}^{2}$ and $2003 / 30 / \mathrm{EC}^{3}$, the European Union as a whole has in 2020 target of a $20 \%$ share of energy from renewable sources and a $10 \%$ share of energy from renewable sources in transport. The countries and regions of central Europe

Received: July 5, 2017; revised: December 17, 2017; accepted: December 29, 2017

$1 \mathrm{http} / /$ eur-lex.europa.eu/legal-content/EN/TXT/?uri=CELEX:32009L0028

$2 \mathrm{http} / / /$ eur-lex.europa.eu/legal-content/en/TXT/?uri=CELEX:32001L0077

$3 \mathrm{http}: / /$ eur-lex.europa.eu/legal-content/EN/TXT/?uri=CELEX:32003L0030\&qid=1498475908984 
vary greatly in their policy frameworks and have a wide disparity in their current performance and 2020 targets, regarding electricity generation, almost all countries are on track for meeting their commitments (Hunkin et al., 2014). For the Czech Republic, the European Commission set a minimum $13 \%$ share of energy from renewable energy sources in gross final energy consumption. Achieving this goal must be also provided with at least a $10 \%$ share of renewables in transport.

Based on statistics of Ministry of Industry and Trade of the Czech Republic (MIT, 2017), the yield of gross production of electricity from renewable sources in 2015 on the total gross electricity generation was $11,23 \%$, the share of renewable energies on primary energy sources was $10,5 \%$ and the share of renewable energy on final energy consumption, in accordance with international methodology of calculation EUROSTAT SHARES, was $15,7 \%$.

Regarding public support instruments, government of the Czech Republic introduced more institutions for support of renewable energy sources. In the field of legislation $^{4}$, the basic law is Act no. 165/2012 Coll., on promoted energy sources and on amendment to some laws and Act no. 458/2000 Coll., on business conditions and public administration in the energy sectors and on amendment to other laws (the "Energy Act"). The law is supplemented by conceptual documents - State energy policy of the Czech Republic (December 2014), National Renewable Energy Action Plan of the Czech Republic (2015) and National Action Plan for Smart Grids (2015). In connection with this law and conceptual documents, there are the following economic instruments supporting renewable electricity generation: grants on investments, feed-in tariffs, green-premiums on electricity prices, tax exemptions, tax reductions and refund of taxes. A feed-in tariff (FIT) is generally a policy mechanism designed to accelerate investment in renewable energy technologies. It achieves this by offering long-term contracts to renewable energy producers, typically based on the cost of generation of each technology. The main goal of feed-in tariffs is to offer cost-based compensation to renewable energy producers, providing price certainty and long-term contracts that help finance renewable energy investments. Under the above law, Energy Regulatory Office sets out the scope and level of support in its price decisions.

It is also valuable to focus in more detail on Nation-

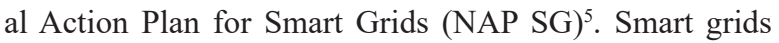
(SG) are defined as the electric networks that are able to effectively link the behaviour and actions of all users connected to them - producers, consumers, prosumers (consumers with their own production) - to ensure the economically efficient, sustainable energy systems operating with low losses and high reliability of supply and safety (MIT,
2015). Regarding the schedule of NAP SG implementation in the Czech Republic, the period up to 2019 can be characterized as a period of preparation, the next period 20202029 represents the gradual implementation of SG, and the period 2030 - 2040 should represent maximum economic efficiency at the required level of "intelligence" of the SG in accordance with the needs of the energy system and the existing technological level at that time (MIT, 2015).

As is mentioned in NAP SG, in connection with the development of renewable energy sources, the anticipated development of small sources, including combined heat and power production, the development of storage capacities and electro-mobility, increases demand on control systems, protection systems, measuring equipment, automation equipment and other elements of the power system.

An integral part of considerations on the integration of intelligent elements into electricity system of the Czech Republic is to ensure cyber security, privacy and information support provided to the client for his decision (MIT, 2015).

Therefore the importance and necessity of economic models in this area is increasing, especially in case of models representing the suitable tool for decision making. The real behaviour and decision making of particular economic entities can be different in situation with or without interactions with other entities - in other words the rules within a group of economic entities can be different than individual entity rules. The approach, which includes also interaction rules, is called ABM - agent based modelling.

The modelling based on the agent based modelling or complex multi-agent modelling has been historically used mainly in the field of engineering and information sciences; however, the importance of this kind of models has been rapidly increasing in the economic sciences and management, mainly in the area of financial markets management, corporate management, water management, waste management, land management, transportation and energy sources management. Applying agent based modelling, the researcher explicitly describes the decision making processes of particular actors at micro level. The structure emerges at the macro level as a result of the actions of the agents and their interactions with each other (Janssen and Ostrom, 2006).

\subsection{Literature overview}

We can find mainly studies analysing and evaluating public policies and public support of renewable energy sources and their success in European countries as a whole (Albrecht et al., 2015; Marques and Fuinhas, 2012) or selected USA countries (Bedsworth and Hanak, 2013); however most of the studies are represented by national case stud-

4 https://www.mpo.cz/en/energy/energy-legislation/

5 https:/www.mpo.cz/dokument158711.html 
ies evaluating domestic economic instruments and state public policies supporting renewable energy sources, for example in Romania (Zamfir et al., 2016), Lithuania (Bobinaite and Tarvydas, 2014) or Spain (Ortega et al., 2013).

Regarding agent models, we can find for example agent-based model with multi-level herding for complex financial systems (Chen et al., 2015), consentaneous agentbased and stochastic model of financial markets (Gontis and Kononovicius, 2014), agent-based double auction markets (Cai et al., 2014) and synthesis of agent-based financial markets and New Keynesian macroeconomics (Lengnick and Wohltmann, 2013). In the field of management, there should be mentioned mainly multi-agent systems for the simulation of land-use and land-cover change (Parker et al., 2003), ecosystem management (Bousquet and Le Page, 2004), urban traffic management and planning (Fiosins et al., 2011) or energy management (Lagorse at al., 2010). There are also studies focused on multi-agent models connected with climate change or carbon emissions reduction, for example the study focused on estimating the impacts of climate change policy on land use (Morgan and Daigneault, 2015) and carbon emissions trading scheme exploration in China (Tang et al., 2015).

Dealing with scientific studies focused on prosumer issues, there are only few studies in this field, since it represents new scientific topic. For example Flaute et al. (2017) investigated the macroeconomic effects of the evolution of prosumer households in the future energy market in Germany, Olkkonen at al. (2017) examined micro-producers of energy as energy "prosumers"-hybrid producers and consumers - and as a challenge to the current logic of energy companies' stakeholder relations in Finland, Zajaczkowska (2016) focused on the current state of the Polish energy sector related to the prosumer energy industry and described the future potential for the development of prosumer energy in Poland. Bellekom et al. (2016) explored the emerging rise of prosumers of electricity and its implications, in particular for grid management and electricity supply in the Netherlands.

In the Czech Republic, we can find mainly economic analyses of renewable energy sources implementation and its economic aspects, for example Ryvolová and Zemplinerová (2010) analysed costs connected with the growth of wind energy supply, Pawliczek (2011) described photovoltaic sector and its development. Prǔša et al. (2013) analysed consumer loss in photovoltaic power plants in the period 2010-2011 and Janda et al. (2014) focused on the total historical and future costs of supporting photovoltaic electricity generation in the Czech Republic. The model estimation of such costs is accompanied by a methodologically unified comparison with the costs of supporting other renewable energy resources. Zimmermannová and Jílková (2016) analysed the relationship between the increase of renewable electricity generation and the progress of public support for renewable electricity.
Analysis of current scientific studies focusing on prosumer issues, using agent-based models, reveals that there is a lack of models dealing simultaneously with economic and environmental issues, mainly in the area of sustainable energy development and reduction of greenhouse gas emissions. Moreover, a dynamic model is needed, since the economic entities have the ability to learn and optimize their behaviour continuously, depending on both external and internal changes in their environment. However, there is also a question of uncertainty, unexpected changes and disturbances in the economic system; therefore we need also methods based on language rules.

Therefore, the general goal of our research is to create an agent model of prosumer. We build on our experiences with the proposal of multi-agent simulation model application in the emission allowances trading area (Zimmermannová and Čermák, 2014) and with creation of a pilot model of a single agent - the broker simulation model in the emission allowances trading area, based on fuzzy logic and language rules (Čermák et al., 2015).

The main goal of this paper is to present new agent model of prosumer and to compare two scenarios - "off grid household" and "on grid household". The additional goal is to evaluate the impact of public support of solar electricity on the economic efficiency of prosumer household projects (systems).

For the purposes of fulfilling all goals of the paper, the following tasks are defined:

1. Firstly, the general structure of the agent model of prosumer will be developed;

2. Secondly, the suitable empirical data will be collected;

3. Two scenarios will be developed - off grid household and on grid household;

4. The agent model of prosumer will be tested and validated, using the empirical data;

5. Then, both scenarios will be compared, focusing on the economic efficiency of particular project;

6. Finally, the evaluation of the impact of public support of solar electricity on the economic efficiency of prosumer household projects (systems) will be provided.

\section{Methods and Data}

\subsection{Methods}

We are going to develop micro-level agent model, representing one household - prosumer. The model has the following characteristics:

- one household with own electricity generation (photovoltaic panels), battery and gasoline unit or distributional network;

- the main goal of this agent will be to cover electricity consumption in household with minimal costs; 
- the primary energy source is a $10 \mathrm{kWp}$ (kilowatt peak) photovoltaic power plant supplemented by a $15 \mathrm{kWp}$ gasoline unit as an alternative energy source;

- the duration of the project is 30 years;

- the prerequisite for the calculation is knowledge of the energy profile of production and consumption of the system (according to the real natural conditions);

- the model works with the average daily values of the household energy profile;

- the key input parameters are the investment costs, precisely costs connected with the purchase of photovoltaic panels, alternative energy source - gasoline unit and battery.

For the purposes of creating of agent model of household - prosumer, we need to use different methods, including statistical methods, econometric methods and nonconventional methods using fuzzy logic.

Figure 1 shows the scheme of the agent model development.

The general model is defined by the parameters, described in the following text.

The inputs to the model are represented by all revenues and expenditures related to the preparation, deployment and operation of photovoltaic power plant, including AMM (Advanced Meter Management) and parameters quantifying elements, activities, entities, or describing boundary conditions of the model's operation.

Input data used for the development of general agent model of prosumer are the following:

- Fixed costs: investment costs (depreciation), overhead (taxes, fees);

- Variable costs: direct operating costs, operating overheads;

- Revenue: produced kWh of electricity and electricity price;
- Subsidies: Subsidy "New Green Savings" 150.000,CZK (approx. 5868 EUR $^{6}$ );

- Discount Rate: official discount rate of Czech National Bank, including prediction;

- Alternative fuel prices (N95): empirical data from the period 1995 - 2016, including prediction;

Output data of the general agent model of prosumer (for the purposes of this paper) are the following:

- Revenue: savings connected with own electricity production;

- Cash flow, discounted cash flow, cumulative cash flow;

- Payback period;

- Net present value (NPV);

- Internal rate of return (IRR).

Payback period is an investment evaluation method that tracks the moment (expressed in years) when the funds (capital expenditures) are returned to the investment expended. For the purposes of calculation of the payback period we can use Cumulative Cash Flow (CCF):

where $\mathrm{N}$ represents the total number of years of operation

$$
C C F=\sum_{n=0}^{N} R_{n}
$$

of the investment, $\mathrm{n}$ are the current years of operation of the investment, $\mathrm{Rn}$ is the net cash flow in each year of the investment's operation. At the moment, when the cumulative cash flow (CCF) is positive, this year $\mathrm{n}$ represents a payback period. CCF can be discounted.

Net Present Value (NPV) - quantifies the current value of all cash flows over the life of the investment at the specific interest rate or required rate of return. The general formula for the NPV calculation is the following:

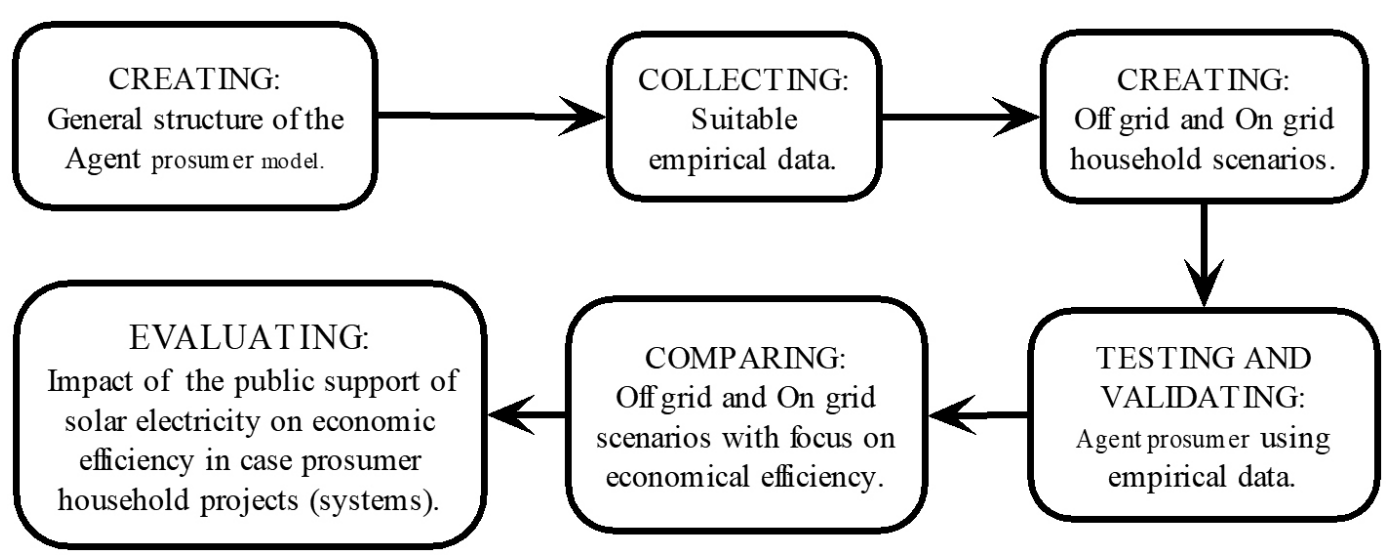

Figure 1: The scheme of the agent model development. Source: authors

$61 \mathrm{EUR}=25.56225$ CZK (Exchange Rate 10.12.2017) 


$$
N P V=\sum_{n=0}^{N} \frac{R_{n}}{(1+i)^{n}}
$$

where $i$ is the required return/interest (discount) rate.

Internal Rate of Return (IRR) is a similar approach to investment evaluation that applies the net present value. However, the IRR seeks to answer the question: "At what interest rate (required profitability) will the net present value be zero?" IRR also represents a dynamic method and it is given by the following equation:

$$
N P V=\sum_{n=0}^{N} \frac{R_{n}}{(1+I R R)^{n}}=0
$$

where the symbols correspond to NPV. The higher IRR of a particular investment or project represents the better solution.

\subsection{Data}

We have original dataset of daily production of electricity from photovoltaic power plant, installed in VSB-TU Ostrava, Faculty of Electrical Engineering and Computer Science; simultaneously we have also original dataset of daily electricity consumption in typical household, mod- elled also in VSB-TU Ostrava ${ }^{7}$. Both original datasets are available for the authors within the project TH01020426 "System for active management of decentralized energy units on local level", financed by the Technology Agency of the Czech Republic. The main goal of the project is to develop, verify and assess a system for active management of energy production, distribution and consumption of an energy unit on local level. The energy unit is a platform with a power output corresponding to a house or office building, which is capable to operate safely and reliably in island mode thus independently on energy supplies from external energy system, and is using mainly local renewable energy sources. The developed system will be highly scalable, ensuring its applicability not only for abovementioned consumers but also for micro-region level (distribution network). The outcomes of the project will be validated using simulation models and pilot-scale trials.

Figure 2 illustrates production and consumption of electric energy of the above mentioned photovoltaic system, including balance calculated as the difference between production and consumption, polynomic trends of $6^{\text {th }}$ degree and 2 day floating average. Points of production and consumption represent average daily values.

Particular technology used in the model is the following: photovoltaic power plant (40 Winaico $250 \mathrm{~W}$ panels), inverters, controllers (Xantrex XW6000, MPPT Xantrex

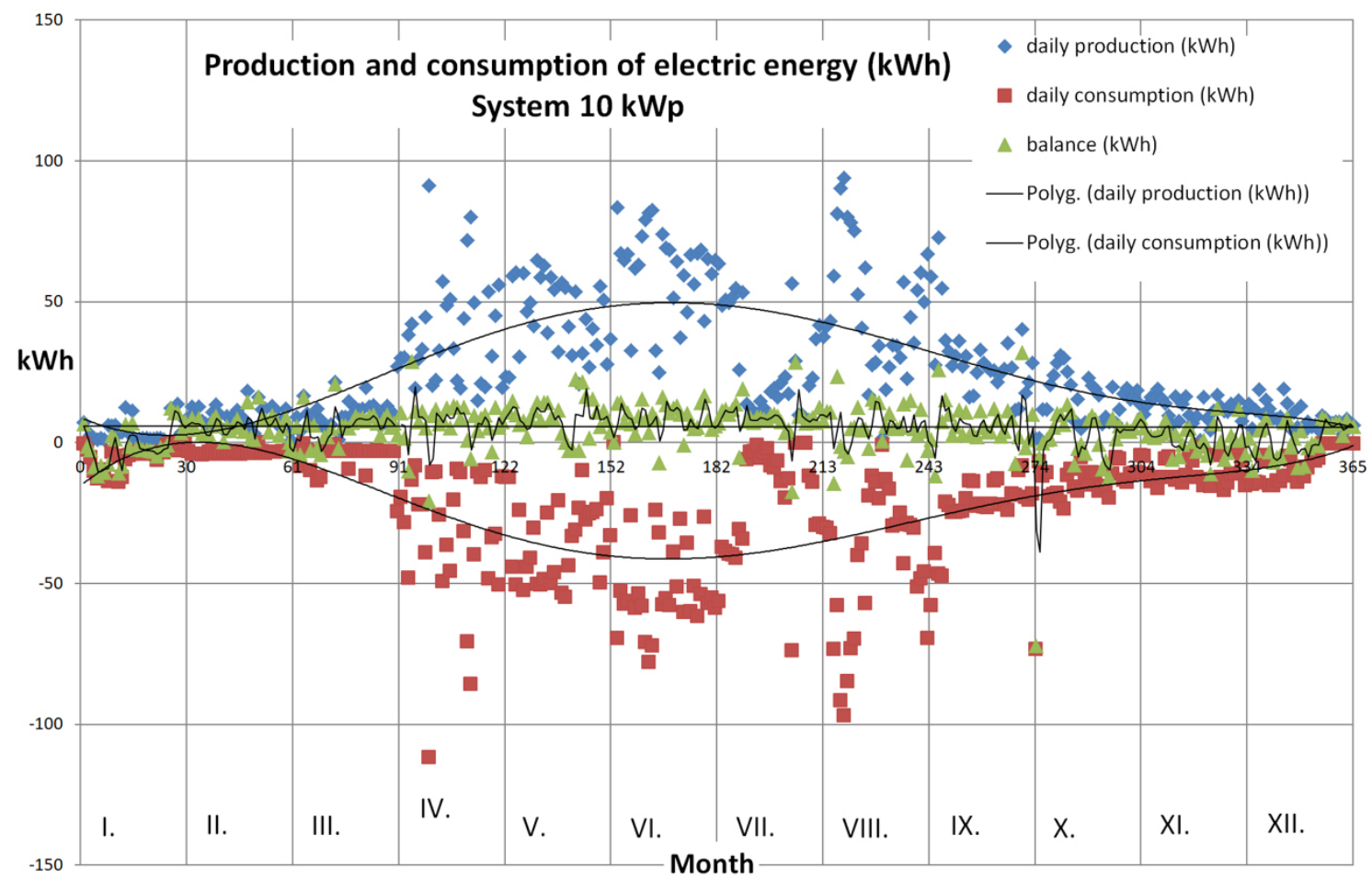

Figure 2: Production and consumption of electric energy-collected empirical data. Source: authors

7 Data are available upon request (corresponding author jarmila.zimmermannova@mvso.cz). 
MPPT80/600), communication (Connect ComBox), accumulation (4 Accu LA3016, 48V, 30Ah, BMS), case (600x800x1200), wiring, fuse, 485/IP, DC/DC). Panel power installed: $10.000 \mathrm{Wp}$, power per panel: $250 \mathrm{Wp}$. Installation geographical locality: VSB-TU Ostrava-Poruba, Moravian-Silesian Region, Czech Republic.

The annual energy profile of our production and consumption system works with the following daily values:

- Daily electricity generation;

- Daily electricity consumption;

- Daily usable production (DUP) - production that can be consumed during the day by the household:

- IF daily production $>$ daily consumption THEN daily usable production = daily consumption;

- IF daily production $\leq$ daily consumption THEN daily usable production = daily production;

- Daily production surplus (DPS) - daily production exceeding the daily consumption that can be sold to the grid:

- IF daily production $>$ daily consumption THEN daily production surplus $=$ daily production - daily consumption;

- IF daily production $\leq$ daily consumption THEN daily production surplus $=0$;

- Daily electricity need for electricity from an alternative source (DEN):

- IF daily production $>$ daily consumption THEN daily electricity need $=0$;

- IF daily production $\leq$ daily consumption THEN daily electricity need $=$ daily consumption - daily production.

Electricity prices for households in the model are represented by empirical data collected in the period 2000 - 2016, added by calculated trends 2017 - 2050 (CZK/ $\mathrm{kWh}$ ), excluding VAT.

Alternative energy source is represented by $15 \mathrm{kWp}$ gasoline unit (HERON EGM 68 AVR-3E ${ }^{8}$ ). Gas prices are represented by empirical data from the period $1995-$ 2016, added by calculated trends $2017-2050$ (CZK / 1), including VAT.

Discount rate (official discount rate of Czech National Bank) is represented by empirical data from the period 1990 - 2017, the annual average value.

For the purposes of feed-in tariff specification, we use data from Energy Regulatory Office (ERO) ${ }^{9}$, precisely feed-in tariffs for electricity generated from renewable energy sources in CZK per MWh in the period 2003-2017.

\section{Scenarios, assumptions and agent model design}

\subsection{Scenarios}

For the purposes of the main goals achievement, the following scenarios are defined:

A. Off grid household "ISLAND" - separate system with battery; the household is completely separate, not connected to the distribution network; the household uses photovoltaic panels as a source of electricity, the extra energy is stored in battery. In case of a lack of electricity, household takes electricity from alternative energy source - gasoline unit. The costs arise only on the household side, the AMM (Advanced Meter Management) system informs the household how much it has produced and how much electricity it has at a given time, including the prediction.

B. On grid household "PARTIAL ISLAND" - connected system with battery; the household is connected to the distribution network, firstly consumes electricity from own sources, then from the grid, production surpluses are supplied to the grid; the household uses photovoltaics as a source of energy, the extra energy is stored in batteries. In case of a lack of electricity, household takes electricity from the distribution network. Costs and revenues are generated on the household side and on the distribution side, the AMM (Advanced Meter Management) system informs the household how much it has produced and how much electricity is available at the given time and also ensures switching between the individual sources - solar panels, batteries and distribution network.

\subsection{Assumptions}

The following Table 1 describes detailed characteristics of the scenario "ISLAND", which are additional to the general characteristics of the agent model of prosumer.

The detailed characteristics of the scenario "PARTIAL ISLAND" is similar like in the previous scenario "ISLAND"; however some characteristics are different - they are described in the following Table 2.

Focusing on public support impact issues, we calculate in our scenarios also with subsidy "New Green Savings", regulated by the Ministry of the Environment of the Czech Republic. For the purposes of our research, we use the highest level of the subsidy - 150.000 CZK (approx. 5868 EUR) for one solar electricity project.

$8 \mathrm{http}: / /$ www.heron-motor.cz/media/attachments/catalog_product/22/8896120_1.pdf

$9 \mathrm{https} / / /$ www.eru.cz/en/poze 


\subsection{General model - agent prosumer}

The following Figure 3 presents the structure of general agent model of prosumer.

Regarding the Figure 3, EC1 - ECn represent particular energy consumers (electrical equipment in household and the rules of electricity consumption for each of them), EG1 - EGm represent individual energy generators and the profile of their electricity generation, E-OPER1 - E-OPERk represent particular energy operators on the market, EC MIX represents energy consumption mix, precisely all rules based on definition of energy consumer devices switching profile (day of week, time), the other variables in the model are Environmental and natural conditions Online - Sensors and Offline - external Database (Internet, Organization CHI Aladin...). In the middle of the mod- el there we can find the decision-making unit - switcher, mixer which we can define better as E-broker.

For the purposes of the model development, the following steps are needed:

1. Energy production data collection and connected prediction based on environmental and natural conditions;

2. Energy consumption data collection and connected prediction based on consumption of household;

3. Optimization of energy consumption mix, including costs connected with energy consumption/production;

4. Optimization of selection of energy generator and/or energy operator; it depends on particular scenarios.

Table 1: Detailed characteristics of the scenario "ISLAND". Source: authors

\begin{tabular}{|c|c|}
\hline Cash OUT - investment costs & $\begin{array}{l}\text { Converters, regulators, communications, control unit. } \\
\text { Accumulation - battery lifetime }=15 \text { years, expected price decrease for } \\
\text { new battery }=25 \% \text {. } \\
\text { Power generator lifetime }=10 \text { years, new power station is expected to } \\
\text { be purchased at the discounted purchase price. }\end{array}$ \\
\hline Cash OUT - operation costs & $\begin{array}{l}\text { Maintenance - regular maintenance costs are assumed every } 5 \text { years. } \\
\text { Wages and material - regular annual cleaning costs of panels. } \\
\text { Energy (fuel) - regular annual fuel cost for alternative electricity source } \\
\text { (N95). } \\
\text { Direct (unit variable costs) }\end{array}$ \\
\hline Cash IN & Revenue (savings from own electricity production). \\
\hline Revenue (savings from production) in CZK & Total annual savings from own electricity production. \\
\hline Saving from production PV annual empirical (kWh) & Annual sum (revenue). \\
\hline Technical correction & Loss of efficiency about $1 \%$ per year. \\
\hline Electricity price & $\begin{array}{l}\text { Forecast of electricity price trend calculated by non-linear (exponential) } \\
\text { model. }\end{array}$ \\
\hline Discount Rate & $\begin{array}{l}\text { Forecast of discount rate trend calculated by non-linear (exponential) } \\
\text { model. }\end{array}$ \\
\hline
\end{tabular}

Table 2: Detailed characteristics of the scenario "PARTIAL ISLAND". Source: authors

\begin{tabular}{|l|l|}
\hline Cash OUT - investments & Power Generator costs $=0$. \\
\hline Cash OUT - operation & $\begin{array}{l}\text { Energy - regular annual costs connected with electricity purchased } \\
\text { from the grid. }\end{array}$ \\
\hline Cash IN & $\begin{array}{l}\text { Revenues (production savings) + revenues from sales of production } \\
\text { surplus. }\end{array}$ \\
\hline Production surplus $(\mathrm{kWh})$ & Annual sum of daily surpluses. \\
\hline Production surplus corrected $(\mathrm{kWh})$ & $\begin{array}{l}\text { Production surplus after correction of loss of efficiency about } 1 \% \text { per } \\
\text { year. }\end{array}$ \\
\hline Feed-in tariff - price for electricity supply $(\mathrm{CZK} / \mathrm{kWh})$ & $\begin{array}{l}\text { Feed-in tariff with annual valorization of } 2 \% \text {. Minimal feed-in tariff } \\
3410 \mathrm{CZK} / \mathrm{MWh}(\text { approx.133 EUR). }\end{array}$ \\
\hline Revenues from sales of production surplus & Production surplus corrected * feed-in tariff \\
\hline
\end{tabular}




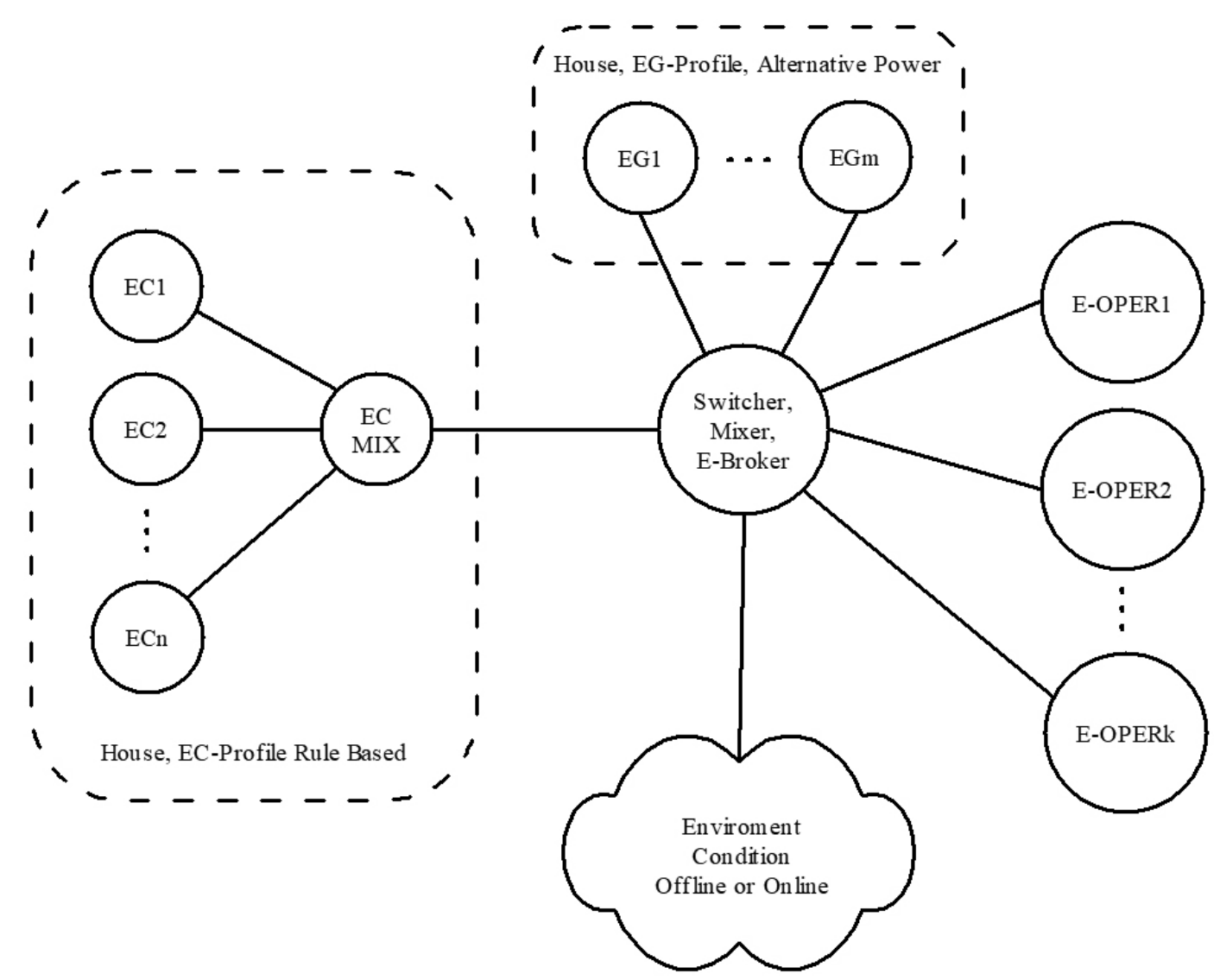

Figure 3: The structure of agent model of prosumer. Source: authors

Energy production and energy consumption data (step 1, step 2) were collected in VSB-TU Ostrava during the period 2015 - 2016, predictions were calculated using empirical data.

In the following part of this paper, we will focus in more detail on step 3 - optimization of energy consumption mix, partially also connected with step 4 - optimization selection of energy generator and/or energy operator.

\section{Results}

\subsection{Economic aspects of scenarios "ISLAND" and "PARTIAL ISLAND"}

Firstly, we should focus on the issue of optimization of energy consumption mix and the economic aspects of the scenario "ISLAND".

Figure 4 shows us the economic aspects of the scenario "ISLAND", precisely cash flow, cumulative cash flow, discounted cumulative cash flow and payback period.

Within this "ISLAND" scenario, cumulative cash flow indicator as well as discounted cumulative cash flow indi- cator have increasing trend during the whole time of the solar electricity project (precisely 30 years), except the $15^{\text {th }}$ year. In this year we can observe sharp decline, connected with the battery replacement, since the service lifetime of the battery is approximately 15 years. Therefore the household - prosumer should expect additional costs connected with new battery purchase and installation in $15^{\text {th }}$ year of the project.

Regarding other useful economic indicator, payback period, Figure 4 shows us, that the project is not very effective. The payback period is represented by approximately $23-24$ years.

Secondly, we should focus on the optimization of energy consumption mix and the economic aspects of the scenario "PARTIAL ISLAND".

In this scenario, consumption of electricity in our household is primarily covered by photovoltaic production and battery accumulation, the household - prosumer can also purchase electricity from grid. However, eventual surpluses of electricity can be also sold to the grid, potential revenues depend on current market price or minimal feedin tariff (it is the case of our scenario).

Figure 5 shows the economic aspects of the scenar- 


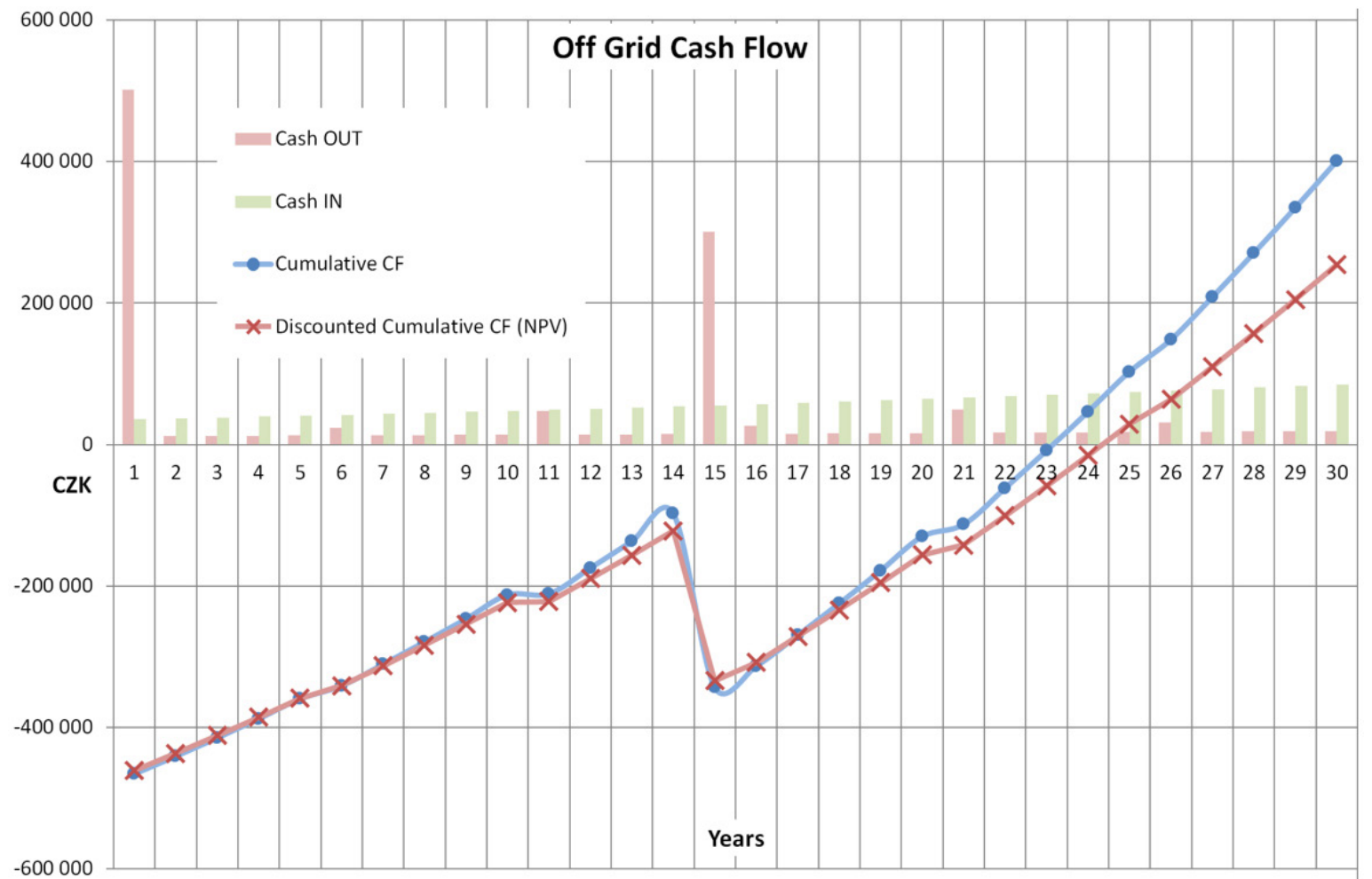

Figure 4: Economic aspects of the scenario "ISLAND" - no subsidy. Source: authors

io "PARTIAL ISLAND", precisely cash flow, cumulative cash flow and payback period. We can observe the similar trends of cumulative and discounted cumulative cash flow, including the year of battery replacement. On the other hand, due to the possibility of electricity surplus selling to the grid and no need to invest to the alternative energy source - gasoline unit, the payback period looks much more interesting for possible investors. Figure 5 shows that the payback period is represented by approximately 18-19 years.

\subsection{Impact of public support}

As is mentioned in the previous chapters, we will compare the basic scenarios "ISLAND" and "PARTIAL ISLAND" with scenarios including public support of solar electricity, precisely the subsidy "New Green Savings" (NGS), regulated by the Ministry of the Environment of the Czech Republic. For the purposes of our research, we use the highest level of this subsidy - 150.000 CZK (approx. 5868 EUR) for one solar electricity project.

Figure 6 shows us the economic aspects of the scenario "ISLAND", including this subsidy.

It is obvious, that the trend lines of cumulative cash flow and discounted cumulative cash flow are similar like in the basic scenario "ISLAND" without subsidy; however the impact of subsidy on the payback period is significant. Figure 6 shows us, that in the scenario "ISLAND" including subsidy the payback period is represented by approximately $20-21$ years. Comparing with the payback period in the scenario "ISLAND" without subsidy, we can see that the project will be effective approximately 3 years earlier.

Figure 7 shows us the economic aspects of the scenario "ISLAND" including the subsidy.

Also the scenario "PARTIAL ISLAND" including subsidy shows us better economic results than the same scenario with no subsidy - the impact of subsidy on the payback period is significant. Figure 7 demonstrates that in the scenario "ISLAND" including subsidy the payback period is represented by approximately 9 years, respectively 15 years, including purchase of new battery. Comparing this result with the payback period in the scenario "PARTIAL ISLAND" without subsidy, we can see that the project will be effective approximately 4 years earlier.

\subsection{Comparison of selected economic indicators}

This sub-chapter is focused on the comparison of selected economic indicators of particular scenarios, precisely cash flow (CF), cumulative cash flow, discounted cash flow, net present value (NPV) and internal rate of return (IRR). 


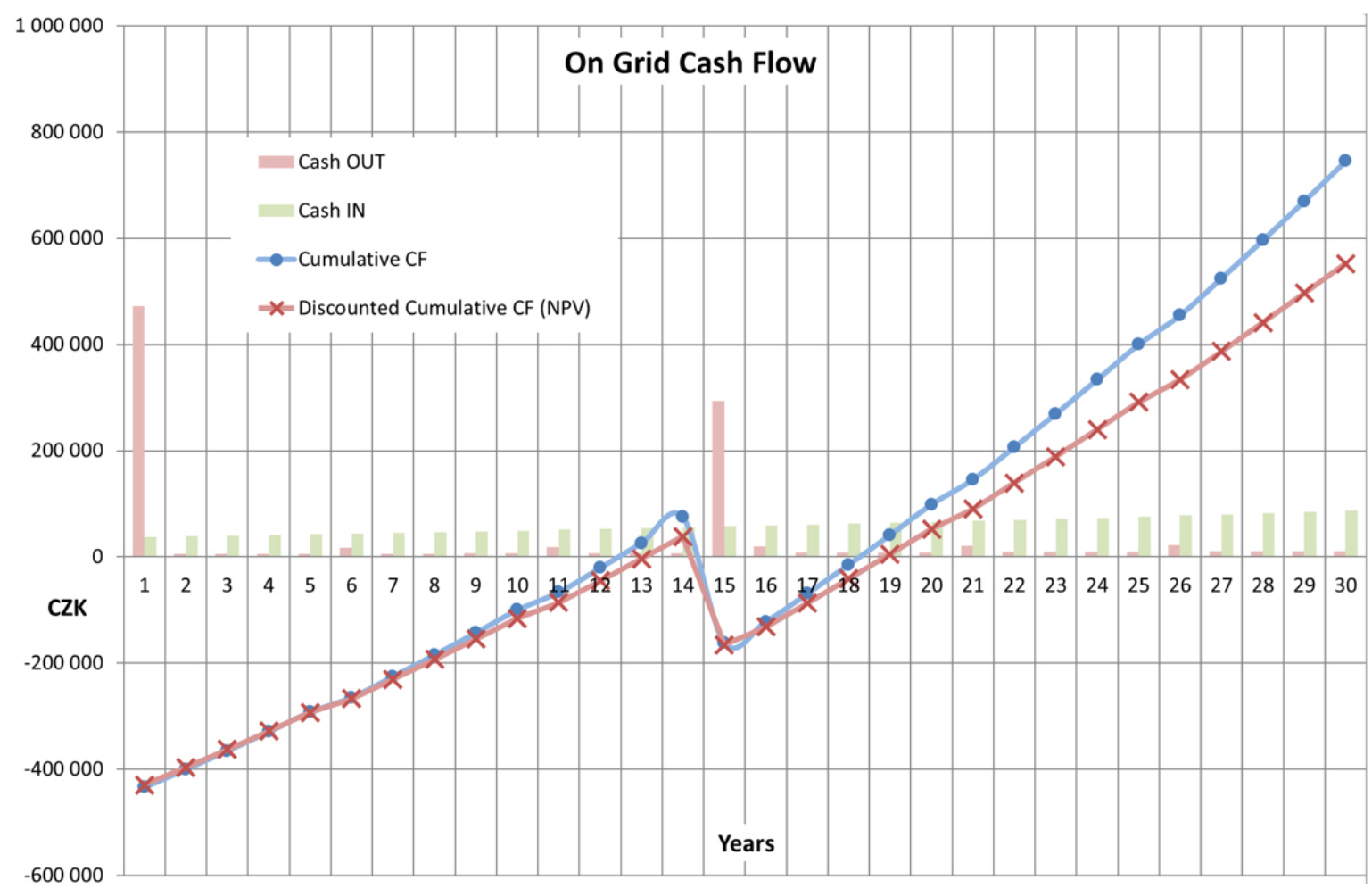

Figure 5: Economic aspects of the scenario "PARTIAL ISLAND - no subsidy. Source: authors

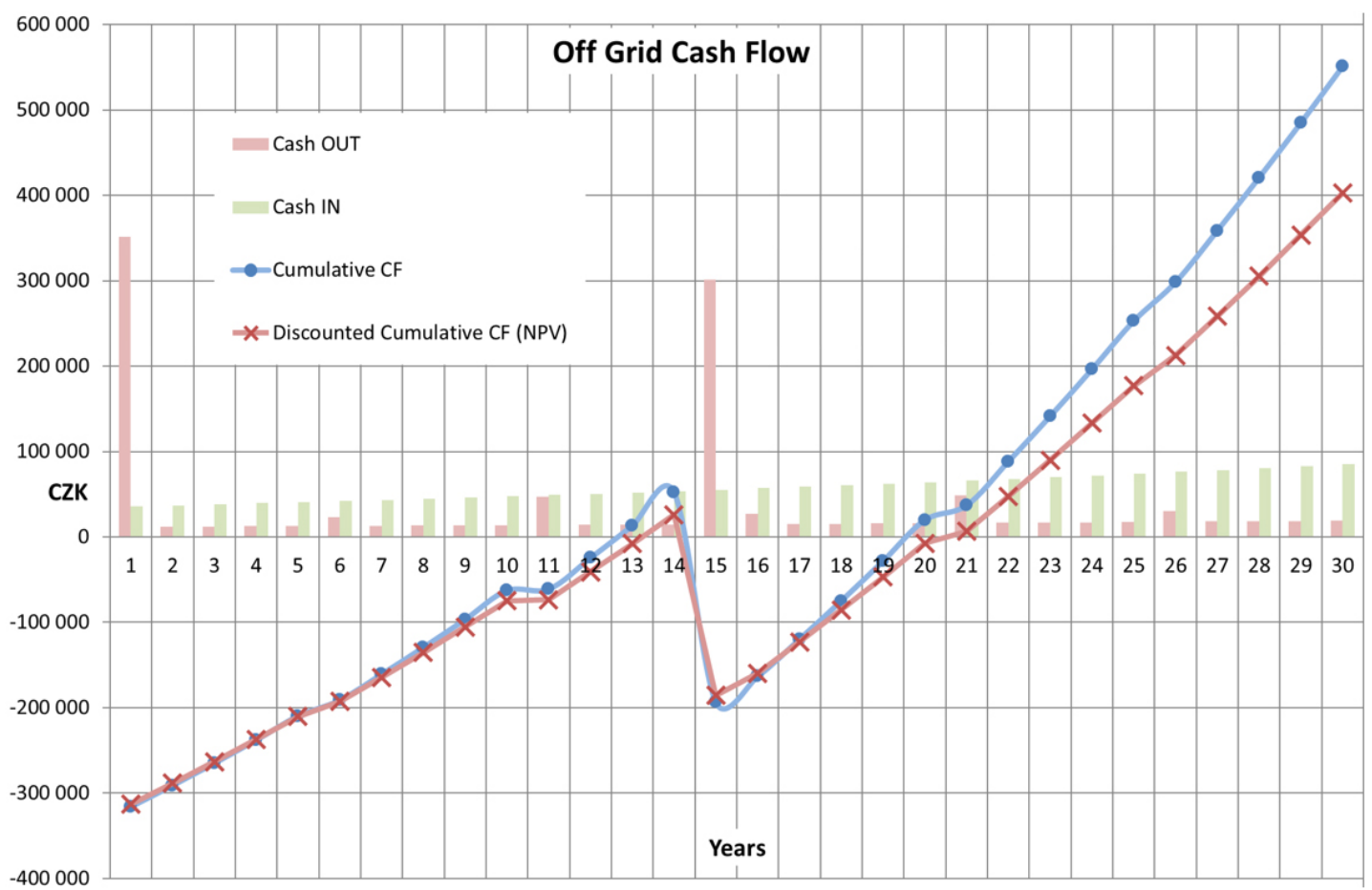

Figure 6: Economic aspects of the scenario "ISLAND" - subsidy NGS. Source: authors 


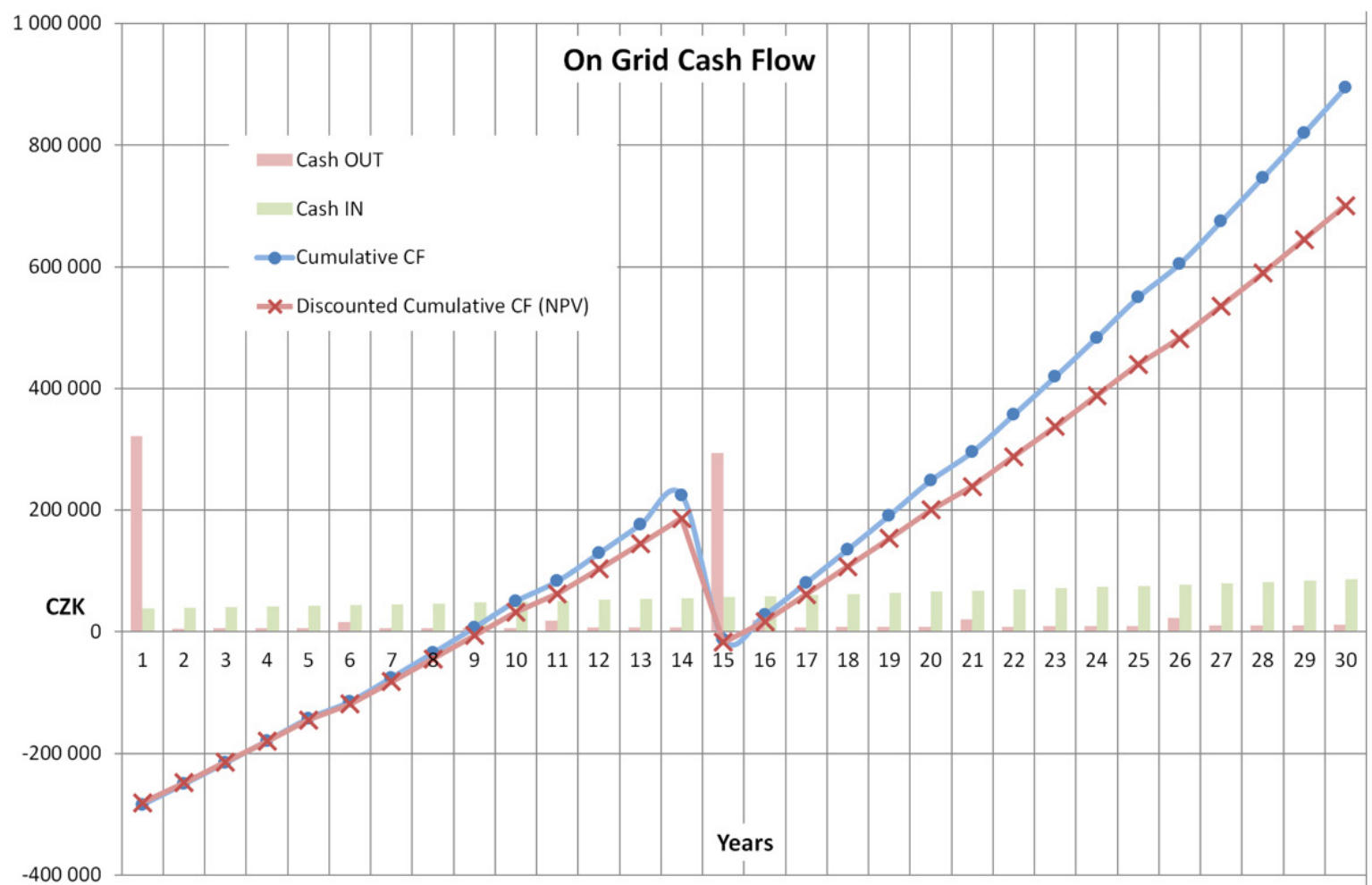

Figure 7: Economic aspects of the scenario "PARTIAL ISLAND" - with subsidy. Source: authors

Table 3: Results for the scenario "ISLAND" (in CZK) - no subsidy. Source: authors

\begin{tabular}{|l|c|c|c|c|c|c|c|}
\hline Year & 1 & 5 & 10 & 15 & 20 & 25 & 30 \\
\hline Cash Flow & -465892 & 28107 & 33907 & -245837 & 48100 & 56601 & 66071 \\
\hline Cumul. CF & -465892 & -259733 & -212738 & -343551 & -130251 & 102798 & 400873 \\
\hline Disc. CF & -461279 & 26743 & 30695 & -211752 & 39420 & 44135 & 49020 \\
\hline NPV & -461279 & -358797 & -223341 & -334016 & -155999 & 28742 & 254018 \\
\hline IRR & --- & $-41,00 \%$ & $-11,16 \%$ & --- & $-4,33 \%$ & $0,45 \%$ & $2,67 \%$ \\
\hline
\end{tabular}

Table 4: Results for the scenario "ISLAND" (in CZK) - with subsidy. Source: authors

\begin{tabular}{|c|c|c|c|c|c|c|c|}
\hline Year & 1 & 5 & 10 & 15 & 20 & 25 & 30 \\
\hline Cash Flow & - 315892 & 28107 & 33907 & - 245837 & 48100 & 56601 & 66071 \\
\hline Cumul. CF & - 315892 & 209733 & 62738 & - 193551 & 19749 & 252798 & 550873 \\
\hline Disc. CF & - $\quad 312764$ & 26743 & 30695 & - 211752 & 39420 & 44135 & 49020 \\
\hline NPV & - $\quad 312764$ & 210282 & 74826 & - 185501 & 7485 & 177257 & 402533 \\
\hline IRR & -- & $-33,06 \%$ & $-4,96 \%$ & -- & $-0,29 \%$ & $3,73 \%$ & $5,56 \%$ \\
\hline
\end{tabular}

Table 5: Results for the scenario "PARTIAL ISLAND" (in CZK) - no subsidy. Source: authors

\begin{tabular}{|l|c|c|c|c|c|c|c|}
\hline Year & 1 & 5 & 10 & 15 & 20 & 25 & 30 \\
\hline Cash Flow & -433937 & 37031 & 43081 & -236460 & 57609 & 66141 & 75502 \\
\hline Cumul. CF & -433937 & -292407 & -100026 & -161952 & 98666 & 399645 & 745160 \\
\hline Disc. CF & -429640 & 35234 & 39001 & -203674 & 47213 & 51575 & 56017 \\
\hline NPV & -429640 & -292999 & -115629 & -165381 & 52197 & 291300 & 552485 \\
\hline IRR & --- & $-33,81 \%$ & $-5,70 \%$ & -- & $1,34 \%$ & $4,45 \%$ & $5,89 \%$ \\
\hline
\end{tabular}


Tables 3 and 4 show the development of particular economic indicators for both scenarios "ISLAND" with no subsidy and "ISLAND" including subsidy.

We can see that the subsidy has significant impact on the values of economic indicators, mainly on cumulative cash flow, net present value (NPV) and internal rate of return (IRR). In case of the scenario "ISLAND" with no subsidy, we can observe negative NPV until $25^{\text {th }}$ year of the project, simultaneously with negative cumulative cash flow and negative IRR. The subsidy causes lower investment costs at the beginning of the project, so NPV, cumulative CF and IRR are in positive values earlier - at the end of $20^{\text {th }}$ year of the project.

Tables 5 and 6 show the development of particular economic indicators for next scenarios "PARTIAL ISLAND" with no subsidy and "PARTIAL ISLAND" including subsidy.

Regarding the scenario "PARTIAL ISLAND", we can also observe significant impact of the subsidy on particular values of economic indicators. In case of the scenario "PARTIAL ISLAND" with no subsidy, we can see negative NPV until $20^{\text {th }}$ year of the project, simultaneously with negative cumulative cash flow and negative IRR. On the contrary, the scenario "PARTIAL ISLAND" including subsidy shows positive values of NPV, cumulative CF and IRR in $10^{\text {th }}$ year of the project. However, there are also visible high additional costs connected with replacement of the battery in $15^{\text {th }}$ year of the project, which cause negative values of economic indicators in $15^{\text {th }}$ year of the project. Finally, we can see positive values in $20^{\text {th }}$ year of the project.

The values of economic indicators within all scenarios are corresponding with payback periods, which are demonstrated in the previous chapters (Figures 4 - 7).

\section{Discussion}

Based on the above described results, we should discuss particular scenarios and evaluate the impact of public support on economic efficiency of the households - prosumers projects in the Czech Republic.

We calculate in our model with grant "New Green Savings", which serves for the households under the New
Green Savings Programme, regulated by the Ministry of the Environment of the Czech Republic. Current grant in the total amount 150.000 CZK (approx. 5868 EUR), used for the purposes of technology investment, represents important motivation for the households to invest to the photovoltaics. Within the model, the influence of the grant on the economic indicators of particular scenarios is significant in both scenarios "ISLAND" and "PARTIAL ISLAND". The households - prosumers will definitely prefer the scenario with lower payback period, including the subsidy. Based on the economic indicators of particular scenarios, the most suitable for the households seems the scenario "PARTIAL ISLAND" including subsidy; however, the selection of concrete solution will depend on possibilities and preferences of particular households.

It should be also mentioned, that current level of subsidy represents significant motivation for the households, on the other hand, the previous levels of subsidy (before year 2017) were low and had negligible impact on the economic indicators of particular solar projects. Currently, it is also case of the system of feed-in tariffs. As was mentioned before, Energy Regulatory Office (ERO) publishes price decisions in the Energy Regulation Gazette ${ }^{10}$, support for renewable electricity generation is guaranteed for $15-30$ years, depending on particular renewable energy source. The minimal feed-in tariffs for the photovoltaics are guaranteed for 20 years. Based on the current law, feed-in-tariffs for new producers are calculated every year, whereas the calculations are based on the current investment costs. For existing sources, feed-in-tariffs are increased by $2 \%$ a year, with the exception of plants using biomass, biogas and biofuels.

Figure 8 shows us the development of feed-in-tariffs for the electricity generated in solar power plants, depending on the date of the production start.

We can see that the support for solar power plants differs, depending on the date of the production start. Regardless regular annual increase in particular feed-in-tariffs, we can see also different level of support in the first year of the electricity generation and consequent different level of support in the following years. It should be mentioned, that under current Energy Regulatory Office decision, new producers of electricity from solar power plants have guar-

Table 6: Results for the scenario "PARTIAL ISLAND” (in CZK) - with subsidy. Source: authors

\begin{tabular}{|c|c|c|c|c|c|c|c|}
\hline Year & 1 & 5 & 10 & 15 & 20 & 25 & 30 \\
\hline Cash Flow & - 283937 & 37031 & 43081 & $-\quad 236460$ & 57609 & 66141 & 75502 \\
\hline Cumul. CF & - $\quad 283937$ & - 142407 & 49974 & - $\quad 11952$ & 248666 & 549645 & 895160 \\
\hline Disc. CF & - 281125 & 35234 & 39001 & - 203674 & 47213 & 51575 & 56017 \\
\hline NPV & - 281125 & - $\quad 144484$ & 32886 & 16866 & 200712 & 439815 & 701000 \\
\hline IRR & --- & $-23,51 \%$ & $2,21 \%$ & -- & $7,23 \%$ & $9,35 \%$ & $10,29 \%$ \\
\hline
\end{tabular}

10 https://www.eru.cz/en/erv 


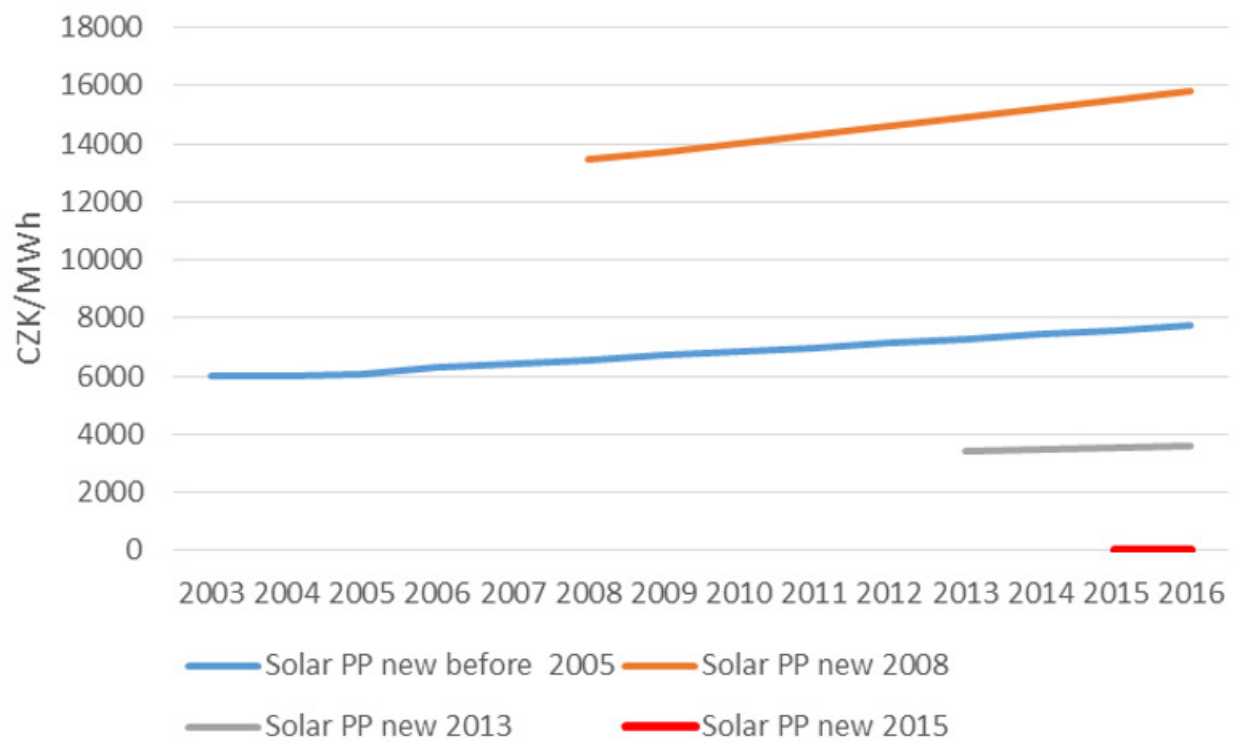

Figure 8: Development of feed-in-tariffs for small solar power plants Source: Zimmermannova, 2017

anteed $0 \mathrm{CZK} / \mathrm{MWh}$ of electricity, the price of electricity supplied by them to the grid depends on current market price.

We should also discuss the restrictions of our model. Firstly, the model is based on the original dataset of daily production of electricity from photovoltaic power plant, installed in VSB-TU Ostrava, and daily electricity consumption in typical household, modelled also in VSB-TU Ostrava. These datasets represent also the data restrictions of the model. For the purposes of development of more detailed model and particular scenarios, we would like to collect data from real photovoltaic systems installed in households.

Second restriction is connected with predictions and price trends for the next 30 years within the model; for example price trends of energy accumulation technology represent important part of costs and significant payback period criterion, especially in the scenario "ISLAND". Currently, we are not able to predict correctly the prices for accumulation systems for the period 2025 - 2040, we can only expect the significant decrease in market price of the accumulation systems and simultaneously higher efficiency of it. Further, it is also hard to predict other factors, as the development of price of photovoltaic panels or market electricity price.

Finally, the model should contain also space dimension, precisely additional variables for the purposes of distinguishing different addresses of particular households prosumers (see for example Meixnerova et al., 2017). It is important since the natural conditions can have significant impact on both production and consumption of electricity.

Comparing our results with results of international scientific studies in the field of households - prosumers, it is obvious, that the main focus of these studies is slightly different. For example Flaute (Flaute et al., 2017) observes effects of households - prosumers on the macroeconomic indicators. The authors conclude that both the investments in power generating technologies and the higher income of households - prosumers due to self-produced electricity lead to higher consumption and stimulate economic growth. At the same time, the increase of prosumer households reduces emissions.

Olkkonen et al. (2017) clarify the role of the energy prosumer as a new type of stakeholder and connects prosumer relations to the notion of co-production. Thus, the article offers valuable information for energy companies when they update their business models to embrace prosumer relations and community involvement. Also Bellekom et al. (2016) focus on trends which affect current business models of DSOs and electricity production and supply companies. The latter are facing a loss of turnover which needs to be compensated by developing alternative business models. And DSOs have to deal with the new needs on the local grid which also require an adaptation of their business models. Developing business models in cooperation with local energy communities could be an attractive alternative to explore.

Our study can represent additional "brick to the wall", since our results observe the economic indicators of particular household - prosumer. Particular household - prosumer can also participate as a stakeholder in the local energy grid and cooperate with energy companies - producers, distributors etc.

Regarding general support of households - prosumers in the society, it should be mentioned, that there are two possibilities of households - prosumers encouragement. 
On the one hand, it is public support, including both economic instruments (grants, subsidies, feed-in tariffs) and legal instruments (low administrative barriers of solar electricity projects) supporting production of renewable electricity. On the other hand, the second kind of support is represented by particular energy and/or distributional company itself, which can motivate the households offering the motivation level of the electricity purchase price.

As is described in the introduction part, the government of the Czech Republic introduced more institutions for support of renewable energy sources, including the following economic instruments: grants on investments, feed-in tariffs, green-premiums on electricity prices, tax exemptions, tax reductions and refund of taxes. Focusing on the results of our scenarios, we recommend to the government to continue with current system of subsidies, since it contributes to lower payback period of the solar electricity projects of households - prosumers. On the other hand, the level of subsidy should be at the same or higher level, for the purposes of representing the significant part of the investment costs. Low level of subsidy has negligible impact on the economic indicators of households prosumers. Regarding feed-in tariffs, the minimal feed-in tariff for new solar sources is currently zero, therefore the energy companies and distributors are electricity purchase price setters. Based on this situation, we recommend to the government also to support development of households - prosumers friendly environment in the regional energy markets, since it can lead to mutual benefits on both sides of households and companies and new system of regional electricity grids.

\section{Conclusions}

The main goal of this paper was to present new agent model of prosumer and to compare two scenarios - "off grid household" and "on grid household". The additional goal was to evaluate the impact of public support of solar electricity on economic efficiency of prosumer household projects (systems). Firstly, the general structure of the agent model of prosumer was developed and the suitable empirical data were collected. Secondly, two scenarios were developed, precisely off grid household (scenario "ISLAND") and on grid household (scenario "PARTIAL ISLAND"). The agent model of prosumer was tested and validated, using the empirical data from VSB-TU Ostrava. Then, both scenarios were compared, focusing on the economic efficiency of particular projects. Finally, the evaluation of the impact of public support of solar electricity on the economic efficiency of prosumer household projects (systems) was provided, including discussion of possible consequences.

Based on our research, it is obvious, that public support - in our case the highest level of subsidy "New Green Savings" has significant impact on the economic indi- cators of both selected scenarios "ISLAND" and "PARTIAL ISLAND". It causes lower investment costs at the beginning of the project and consequently shorter payback period (3-4 years earlier), positive cumulative cash flow, net present value and IRR in earlier period (approximately 5-10 years earlier, depending on the scenario). However, besides public support, there is also possibility of private support of households - prosumers, represented by the level of electricity purchase price, set by energy and/or distributional companies, which can motivate particular households to invest to photovoltaics.

In the following research, we should focus on the collection of the additional data from real households-prosumers and the expansion of our dataset. We would like also to add spatial variables to the model for the purposes of distinguishing different locations of the households; it can bring interesting results and prepare more sophisticated scenarios. Finally, it is also necessary to try to update the model in regular intervals, based on the development of particular input variables of the model.

\section{Acknowledgements}

Presented research was supported by the project TH01020426 "System for active management of decentralized energy units on local level", financed by the Technology Agency of the Czech Republic.

\section{References}

Albrecht, J., Laleman, R., \& Vulsteke, E. (2015). Balancing demand-pull and supply-push measures to support renewable electricity in Europe. Renewable and Sustainable Energy Reviews; 49 (Sep 2015) 267-277, https://doi.org/10.1016/j.rser.2015.04.078

Bedsworth, L.W., \& Hanak, E. (2013). Climate policy at local level: Insights from California. Global Environmental Change - Human and Policy Dimensions; 23 (3), 667-677.

Bellekom, S., Arentsen, M., \& Van Gorkum, K. (2016). Prosumption and the distribution and supply of electricity. Energy, sustainability and society, 6(1), 22, http://dx.doi.org/10.1186/s13705-016-0087-7

Bobinaite, V., \& Tarvydas, D. (2014). Financing instruments and channels for the increasing production and consumption of renewable energy: Lithuanian Case. Renewable and Sustainable Energy Reviews; 38 (Oct 2014) 259-276, http://dx.doi.org/10.1016/j. rser.2014.05.039

Bousquet, F., \& Le Page, C. (2004). Multi-agent simulations and ecosystem management: a review. Ecological Modelling, 176 (3-4), 313-332, http://dx.doi. org/10.1016/j.ecolmodel.2004.01.011

Cai, K., Niu, J.Z., \& Parsons, S. (2014). On the effects 
of competition between agent-based double auction markets. Electronic Commerce Research and Applications, 13 (4), 229-242, http://dx.doi.org/10.1016/j. elerap.2014.04.002

Cermak, P., Zimmermannova, J., Lavrincik, J., Pokorny, M., \& Martinu, J. (2015). The Broker Simulation Model in the Emission Allowances Trading Area. International Journal of Energy Economics and Policy, 5 (1), 80-95. ISSN: 2146-4553.

Chen, J.J. Tan, L., \& Zheng, B. (2015). Agent-based model with multi-level herding for complex financial systems. Scientific Reports, 5 (article no. 8399), http:// dx.doi.org/10.1038/srep08399

Fiosins, M., Fiosina, J., Muller, J.P., \& Gormer, J. (2011). Agent-Based Integrated Decision Making for Autonomous Vehicles in Urban Traffic. Advances on Practical Applications of Agents and Multi-Agent Systems. Edited by: Demazeau, Y., Pechoucek, M. Corchado, J.M., \& Bajo, J. Book Series: Advances in Intelligent and Soft Computing, vol. 88, 173-178, http://dx.doi. org/10.1007/978-3-642-19875-5_22

Flaute, M., Großman, A., Lutz, C., \& Nieters, A. (2017). Macroeconomic Effects of Prosumer Households in Germany. International Journal of Energy Economics and Policy 7(1), 146-155.

Gontis, V., \& Kononovicius, A. (2014). Consentaneous Agent-Based and Stochastic Model of the Financial Markets. Plos One, 9 (7), article no. e102201, http:// dx.doi.org/10.1371/journal.pone.0102201

Hunkin, S., Barsoumian, S., Krell, K., Severin, A., \& Corradino, G. (2014). Thematic Study on Energy Efficiency and Renewable Energies. CENTRAL EUROPE Programme, April 2014.

Janda, K., Krška, Š., \& Průša, J. (2014). Czech Photovoltaic Energy: Model Estimation of the Costs of its Support. Politická ekonomie; 62 (3) 323-346.

Janssen, M. A., \& Ostrom, E. (2006). Empirically based, agent-based models. Ecology and Society, 11 (2), art.37. Available from https://www.ecologyandsociety. org/vol11/iss2/art37/

Lagorse, J., Paire, D., \& Miraoui, A. (2010). A multi-agent system for energy management of distributed power sources. Renewable Energy. 35 (1), 174-182. http:// dx.doi.org/10.1016/j.renene.2009.02.029

Lengnick, M., \& Wohltmann, Hw. (2013). Agent-based financial markets and New Keynesian macroeconomics: a synthesis. Journal of Economic Interaction and Coordination, 8 (1), 1-32, http://dx.doi.org/10.1007/ s11403-012-0100-y

Marques, A.C., \& Fuinhas, J.A. (2012). Are public policies towards renewables successful? Evidence from European countries. Renewable Energy; 44 (Aug 2012) $109-118$.

Meixnerová, L., Menšík, M., \& Pászto, V. (2017). Economic analysis and spatial arrangements of engineering
SMEs performance in Olomouc region of Czech Republic. Journal of International Studies, 10(1), 135-145, http://dx.doi.org/10.14254/2071-8330.2017/10-1/9

MIT (Ministry of Industry and Trade of the Czech Republic). (2015). National Action Plan for Smart Grids (NAP SG). Available at: www.mpo.cz

MIT (Ministry of Industry and Trade). (2017). Renewable energy sources in 2015; Results of the survey. Available at: https://www.mpo.cz/assets/cz/energetika/ statistika/obnovitelne-zdroje-energie/2017/2/Obnovitelne-zdroje-energie2015.pdf

Morgan, F.J., \& Daigneault, A.J. (2015). Estimating impacts of climate change policy on land use: An agentbased modelling approach. PLOS ONE, 10 (5), 21 May 2015, article number e0127317.

Olkkonen, L., Korjonen-Kuusipuro, K., \& Grönberg, I. (2017). Redefining a stakeholder relation: Finnish energy "prosumers" as co-producers. Environmental Innovation and Societal Transitions, 24, 57-66.

Ortega, M., Del Rio, P., \& Montero, E.A. (2013). Assessing the benefits and costs of renewable electricity. The Spanish case. Renewable and Sustainable Energy Reviews; 27 (Nov 2013), 294 - 304, https://doi. org/10.24084/repqj14.527

Parker, D.C., Manson, S.M., Janssen, M.A., Hoffmann, M.J., \& Deadman, P. (2003). Multi-agent systems for the simulation of land-use and land-cover change: A review. Annals of the Association of American Geographers, 93 (2), 314-337, http://dx.doi.org/10.1111/14678306.9302004

Pawliczek, A. (2011). Czech Photovoltaic Business and Sustainable Development. The International Conference Hradec Economic Days 2011. Peer-Reviewed Conference Proceedings, Hradec Králové: Gaudeamus, 2011, 214-218, ISBN 978-80-7435-101-3.

Průša, J., Klimešová, A., \& Janda, K. (2013). Consumer loss in Czech photovoltaic power plants in 2010-2011. Energy Policy; 63 (2013) 747-755, http://dx.doi. org/10.1016/j.enpol.2013.08.023

Ryvolová, I., \& Zemplinerová, A. (2010). The Economics of Renewable Energy - Example of Wind Energy in the Czech Republic. Politická ekonomie; 58 (6) 323-346.

Tang, L., Wu, J., Yu, L., \& Bao, Q. (2015). Carbon emissions trading scheme exploration in China: A multi-agentbased model. Energy Policy, 81 (1 June 2015), 152169, http://dx.doi.org/10.1016/j.enpol.2015.02.032

Zajaczkowska, M. (2016). Prospects for the development of prosumer energy in Poland. Oeconomia Copernicana, 7(3), 439-449.

Zamfir, A., Colesca, S.E., \& Corbos, R.A. (2016). Public policies to support the development of renewable energy in Romania: A review. Renewable and Sustainable Energy Reviews; 58 (May 2016) 87-106, http://dx.doi. org/10.1016\%2Fj.rser.2015.12.235

Zimmermannová, J. (2017). Is Current Institutional En- 
vironment Suitable for Renewable Electricity Generation in the Czech Republic? Current Trends in Public Sector Research. Proceedings of the 21st International Conference. Masaryk University, Brno-Šlapanice. 2017, 434 - 442. ISBN 978-80-210-8448-3, ISSN 2336-1239

Zimmermannová, J., \& Čermák, P. (2014). Possibilities of Multiagent Simulation Model Application in the Emission Allowances Trading Area. Procedia Economics and Finance, 2014, vol. 12, 788-796, http://dx.doi. org/10.1016/S2212-5671(14)00406-7

Zimmermannová, J., \& Jílková, E. (2016). Do Economic Instruments in the Czech Republic Support Generation of Renewable Energy? Economics Management Innovation; 8 (2) 16-30.

Jarmila Zimmermannova is an Associate Professor and a Vice-Rector for Science, Research and Development at the Moravian University College Olomouc, Czech Republic. In the period $2003-2009$, she worked at the Ministry of the Environment of the Czech Republic. Her research focuses on financial and economic instruments of the environmental policy, mainly on ex-ante and ex-post analyses of particular economic instruments in the field of air and climate protection. She is the author of a number of scientific articles and the monograph "Environmental Taxation and Modelling of its Impacts".

Adam Pawliczek is an Associate Professor and a Head of the Department of Management and Marketing at the Moravian University College Olomouc, Czech Republic. His research focuses on SMEs and household economics, management tools or renewable energy. He has published more than 40 articles in scientific journals and proceedings of international conferences.

Petr Cermak is an Associate Professor at the Moravian University College Olomouc, Czech Republic. He earned both his $\mathrm{PhD}$ and habilitation in the field of Technical Cybernetics. He also works as a Director of Robotic Laboratory in the Institute of Computer Science in Opava. His research focuses mainly on system modelling using artifical intelligence, fuzzy-neural networks, robotics, digital image processing and analysis. 